\title{
Review
}

\section{Plant diseases that changed the world}

\section{Progress towards the understanding and control of sugar beet rhizomania disease}

\author{
GRAHAM R. D. MCGRANN ${ }^{1}+$, MICHAEL K. GRIMMER², EFFIE S. MUTASA-GÖTTGENS ${ }^{1}$ \\ AND MARK STEVENS ${ }^{1, *}$ \\ 'Broom's Barn Research Centre, Rothamsted Research, Department of Applied Crop Sciences, Higham, Bury St Edmunds, Suffolk IP28 6NP, UK \\ ${ }^{2}$ ADAS Boxworth, Battlegate Rd, Boxworth, Cambridge CB23 4NN, UK
}

\section{SUMMARY}

Rhizomania is a soil-borne disease that occurs throughout the major sugar beet growing regions of the world, causing severe yield losses in the absence of effective control measures. It is caused by Beet necrotic yellow vein virus (BNYVV), which is transmitted by the obligate root-infecting parasite Polymyxa betae. BNYVV has a multipartite RNA genome with all natural isolates containing four RNA species, although some isolates have a fifth RNA. The larger RNA1 and RNA2 contain the housekeeping genes of the virus and are always required for infection, whereas the smaller RNAs are involved in pathogenicity and vector transmission. RNA5-containing isolates are restricted to Asia and some parts of Europe, and these isolates tend to be more aggressive. With no acceptable pesticides available to restrict the vector, the control of rhizomania is now achieved almost exclusively through the use of resistant cultivars. A single dominant resistance gene, $R z 1$, has been used to manage the disease worldwide in recent years, although this gene confers only partial resistance. More recently, new variants of BNYVV have evolved (both with and without RNA5) that are able to cause significant yield penalties on resistant cultivars. These isolates are not yet widespread, but their appearance has resulted in accelerated searches for new sources of resistance to both the virus and the vector. Combined virus and vector resistance, achieved either by conventional or transgenic breeding, offers the sugar beet industry a new approach in its continuing struggle against rhizomania.

\footnotetext{
*Correspondence: Tel.: 01284 812206; Fax: 01284 811191; E-mail: mark.stevens@bbsrc.ac.uk †Present address: Department of Disease and Stress Biology, John Innes Centre, Colney Lane, Norwich NR4 7UH, UK.
}

\section{INTRODUCTION}

Rhizomania disease was first recorded by Canova (1959) who, in 1952, observed instances of poorly growing sugar beet crops in northern Italy; in many cases, crop damage was so severe that cultivation had to be abandoned. These crops had an abnormal proliferation of dark necrotic roots, leading Canova (1966) to name the condition 'rizomania' or 'root madness'. Since its initial discovery, rhizomania (the name subsequently adopted) has been documented in all of the major sugar beet growing regions of Europe and the Middle East (Asher, 1993; Lennefors et al., 2000; Mouhanna et al., 2002; Nielsen et al., 2001; Sohi and Maleki, 2004; Yilmaz et al., 2007), as well as Japan (Kanzawa and Ui, 1972), China (Gao et al., 1983), Morocco [European and Mediterranean Plant Protection Organization (OEPP/EPPO), 2005] and the USA (AI Musa and Mink, 1981) (Table 1), and is likely to continue its spread across the world (Rush et al., 2006). However, it was not until 20 years after the discovery of rhizomania that its cause was identified in Japan, when a virus, named Beet necrotic yellow vein virus (BNYVV), was isolated from infected sugar beet plants (Tamada and Baba, 1973). BNYVV has since been assigned to the genus Benyvirus.

The first sign of rhizomania disease in a sugar beet crop appears as light green or yellow irregularly shaped patches in the field (Fig. 1a), usually during the early months of the growing season. On closer inspection, individual plants show the characteristic proliferation of fibrous roots around the tap root, the 'root madness' symptom of rhizomania (Fig. 1b). Recent proteomic analysis of sugar beet in response to BNYVV infection has shown an induction of phytohormones, such as abscisic acid and auxin, which may be involved in the production of the 'root madness' symptoms characteristic of rhizomania (Larson et al., 2008). In severely infected plants, the tap root and lateral roots become necrotic and die, and the vascular tissue develops a pale brown colouration (Brunt and Richards, 1989). In most cases, it is this damage to the roots that causes the foliar symptoms through 
Table 1 Global distribution and spread of rhizomania disease of sugar beet.

\begin{tabular}{ll}
\hline Country & Year rhizomania discovered* \\
\hline Italy & 1952 \\
Japan & 1965 \\
Croatia & 1971 \\
France & 1971 \\
Former Republic of Yugoslavia & 1972 \\
Greece & 1972 \\
Germany & 1974 \\
Czech Republic & 1978 \\
China & 1978 \\
Slovakia & 1978 \\
Austria & 1979 \\
Kazakhstan & 1979 \\
Romania & 1979 \\
Russia & 1979 \\
Ukraine & 1979 \\
USA & 1981 \\
Hungary & 1982 \\
Bulgaria & 1983 \\
Netherlands & 1983 \\
Switzerland & 1983 \\
Belgium & 1984 \\
UK & 1987 \\
Spain & 1988 \\
Sweden & 1997 \\
Syria & 1998 \\
Denmark & 2000 \\
Turkey & 2001 \\
Poland & 2002 \\
Egypt & 2003 \\
Iran & 2004 \\
Morroco & 2005 \\
\hline & \\
\hline
\end{tabular}

*Compiled from Al Musa and Mink (1981), Asher (1993), Canova (1959), European and Mediterranean Plant Protection Organization (OEPP/EPPO) (2005), Gao et al. (1983), Kanzawa and Ui (1972), Lennefors et al. (2000), Mouhanna et al. (2002); Nielsen et al. (2001), Richard-Molard (1985), Sohi and Maleki (2004) and Yilmaz et al. (2007).

reduced nutrient uptake (Stevens et al., 2006), but, in rare circumstances, BNYVV infection becomes systemic and the leaves show a variety of symptoms, including yellowing, crinkling, wilting and vein yellowing (Fig. 1d) that gives the virus its name (Tamada, 2002; Tamada and Baba, 1973).

Losses to the sugar beet crop can be severe, and the disease is most destructive when plants are infected early in the growing season, which leads to serious decreases in root yield, sugar content and juice purity. Yield penalties can vary depending on the cultivar and environmental factors, with losses of sugar yield in the order of $50 \%-60 \%$ not uncommon, although losses of almost 80\% have been documented (Asher, 1993; Henry, 1996). These yield penalties are the combined result of reduced fresh root weight, which can decrease by as much as $50 \%$, and reduced sugar content in the roots, which can fall by between $8 \%$ and $48 \%$ (Henry, 1996). Moreover, infection with BNYVV

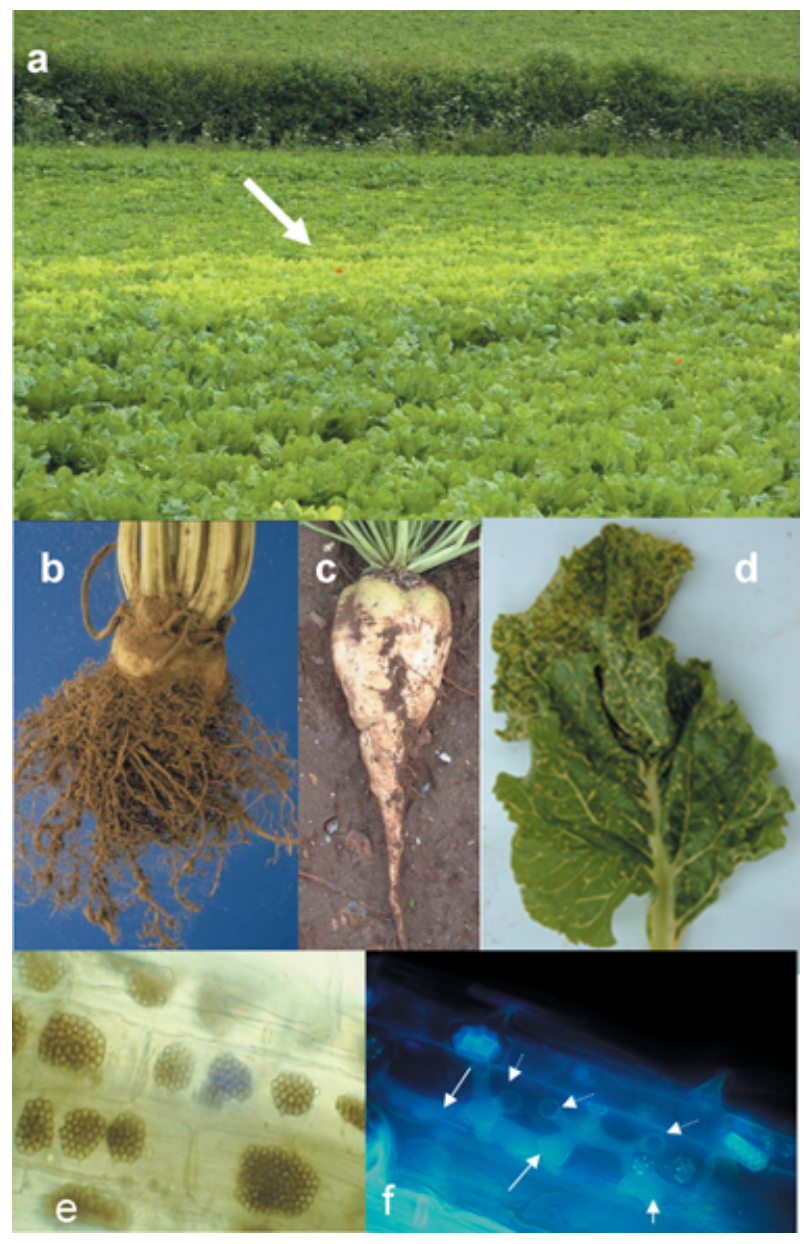

Fig. 1 Symptoms of Beet necrotic yellow vein virus (BNYVV) on sugar beet, and Polymyxa betae, the plasmodiophorid vector of rhizomania. (a) Rhizomania-infected patch (indicated by arrow) typical of BNYVV infection in the field. (b) Classical 'root madness' symptoms in BNYVV-infected sugar beet. (c) A virus-free root. (d) Necrotic yellow vein symptom only observed under optimal disease conditions. (e) Long-lived resting spores in sugar beet roots viewed under the light microscope. (f) Multilobed zoosporangium (solid arrows) inside host root cells after secondary zoospore release. Exit tubes where zoospores were released are visible (dotted arrows). The $P$. betae zoosporangium had been fixed in situ in $10 \%$ formaldehyde, $\mathrm{pH} 7.2$, for at least 3 years prior to being visualised and photographed under the microscope with ultraviolet illumination.

can increase sodium levels in sugar beet (Heijbroek, 1989), and reduce the storage ability, resulting in further losses to the crop (Strausbaugh et al., 2008).

Rhizomania is transmitted by the obligate root-infecting plasmodiophorid parasite Polymyxa betae, and is exclusively a soil-borne disease (Fujisawa and Sugimoto, 1977). The virus is carried internally by $10 \%-15 \%$ of $P$. betae resting spores in the soil (Tuitert, 1990), although the relationship between this inoculum potential and the actual inoculum density of viruliferous $P$. betae 
populations is currently unknown. BNYVV is able to survive for long periods within the thick-walled resting spores of its vector (Fig. 1e). Consequently, the virus can persist in infested soil for many years (Abe and Tamada, 1986); therefore, in practical terms, once a field becomes contaminated with rhizomania, it remains permanently infested (Wisler and Duffus, 2000). Under favourable conditions, $P$. betae resting spores germinate to release motile biflagellate zoospores which are able to swim short distances to find a suitable host. Once a host is located, the zoospores probe the surface of the root until they attach, remaining there for at least $1-2 h$, during which time they form dagger-like bodies that are used to penetrate the host cell wall before injecting the zoospore cytoplasm into the host (Keskin, 1964; Keskin and Fuchs, 1969). It is along with this injection of $P$. betae cytoplasm that BNYVV virus particles are transmitted into host cells. Once inside the host cells, $P$. betae develops by first forming plasmodia, and then multilobed zoosporangia (Fig. 1f) containing many secondary zoospores that can vector the virus. Spread of the disease is primarily through the movement of soil, mainly by machinery and/or attached to harvested roots; water also plays an important role in facilitating the local spread of $P$. betae zoospores throughout fields (Asher, 1993; Heijbroek, 1987). It is generally accepted that BNYVV does not replicate inside $P$. betae, but recent evidence from Verchot-Lubicz et al. (2007) suggests that this may not necessarily be the case. Immunofluorescent microscopy identified the BNYVV proteins involved in virus replication, virus assembly and virus movement within $P$. betae resting spores and zoospores, suggesting that viral translation may be occurring within the vector. This is interesting and clearly warrants further investigation to determine whether $P$. betae is actually a host for BNYVV or simply a vehicle for virus transmission. The relationship between the virus and its vector has been reviewed in more detail elsewhere (Rush, 2003).

\section{GENOME STRUCTURE OF BNYVV}

Beet necrotic yellow vein virus (BNYVV) is the type member of the genus Benyvirus and is a single-stranded RNA virus with tubular rod-shaped particles (Fig. 2a), $20 \mathrm{~nm}$ in diameter, and of five modal lengths ranging from 80 to $390 \mathrm{~nm}$. Each RNA species is 5'-capped and 3'-polyadenylated (Richards and Tamada, 1992). All isolates of BNYVV contain species RNA1-RNA4, and some from Europe and Asia contain the additional RNA5 (Fig. 2b). RNA1 comprises one large open reading frame (ORF) that is 6746 nucleotides long, encoding a single protein, p237, of $237 \mathrm{kDa}$ and containing the RNA-dependent RNA polymerase for virus replication (Bouzoubaa et al., 1987; Richards and Tamada, 1992). p237 is autocatalytically cleaved after translation into p150 and p66. The p150 protein contains methyltransferase, helicase and papain-like protease domains, whereas the entire polymerase domain is found within p66 (Hehn et al., 1997). a

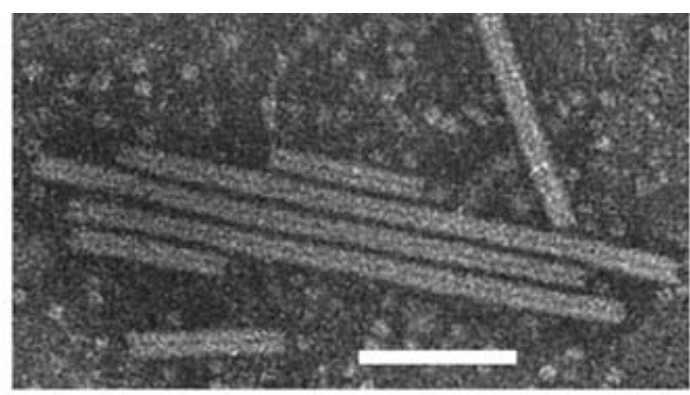

b

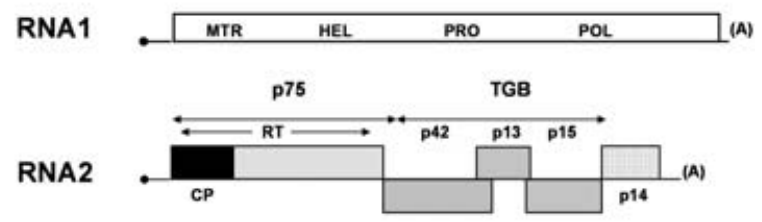

RNA 3

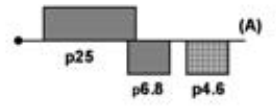

(A) RNA 4
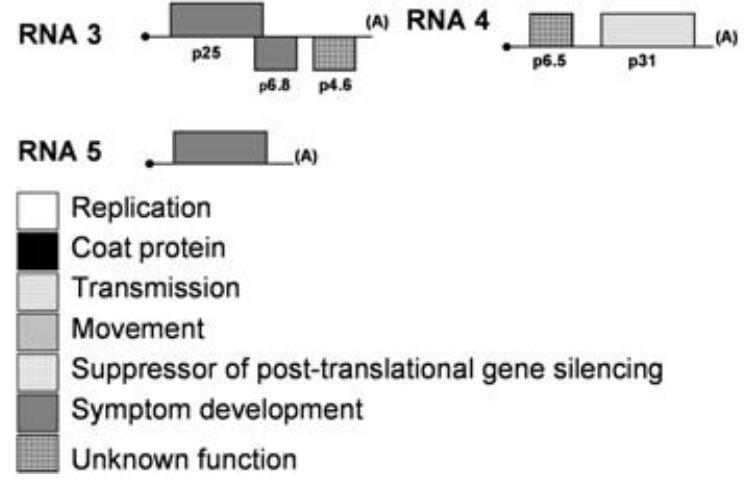

Fig. 2 Beet necrotic yellow vein virus (BNYVV), the cause of rhizomania. (a) Electron micrograph of BNYVV particles [courtesy Descriptions of Plant Viruses No. 391 (Tamada, 2002), http://www.dpvweb.net/dpv/ showdpv.php?dpvno=391, with permission from the Association of Applied Biologists). Scale bar represents $100 \mathrm{~nm}$. (b) BNYVV genome map showing multipartite organisation of viral proteins. CP, coat protein; HEL, helicase; MTR, methyltransferase; POL, polymerase; PRO, protease; RT, read-through protein.

RNA2 is 4612 nucleotides long and contains six ORFs (Bouzoubaa et al., 1986). The proximal 5' ORF encodes the 21-kDa major coat protein (CP), which is separated from the second 54-kDa ORF by a 'leaky' amber termination codon that undergoes suppression approximately $10 \%$ of the time during translation, resulting in a 75-kDa fusion protein referred to as the p75 read-through protein (Schmitt et al., 1992). The N-terminal part of p75 encodes a minor $\mathrm{CP}$ important for the formation of the rod-shaped virions of BNYVV, and the C-terminal portion of this read-through protein is essential for transmission by $P$. betae. Serial passage of field isolates of BNYVV through the leaves of the experimental indicator host species Chenopodium quinoa and Tetragonia expansa by mechanical transmission results in deletions to RNA2 in the second ORF that prevent vector transmission (Koenig, 2000; Tamada and 
Kusume, 1991). Further analysis of this region identified a KTER motif that is vital for efficient vector transmission (Tamada et al., 1996b). Deletions in the RNA2 read-through proteins of plasmodiophorid-transmitted viruses of the genera Benyvirus, Furovirus and Pomovirus, following non-vector-mediated transmission, appear to be common. This phenomenon has also been observed in other plasmodiophorid-transmitted viruses that do not possess a read-through protein, such as those in the genera Bymovirus and Pecluvirus. It is hypothesized that these genomic regions of plasmodiophorid-transmitted viruses encode transmembrane domains that are involved in attachment to the vector plasmalemma and in aiding virion transmission between plant and vector cytoplasm (Adams et al., 2001). p75 also appears to be involved in the targeting of virus assembly to the mitochondria of host cells (Erhardt et al., 2001; Valentin et al., 2005).

The central region of RNA2 contains a grouped set of three overlapping ORFs, termed the 'triple gene block' (TGB). This TGB encodes proteins of 42,13 and $15 \mathrm{kDa}$ that are required for efficient cell-to-cell movement of BNYVV (Gilmer et al., 1992). The p13 and p15 proteins both localise to cell wall thickenings that are believed to represent degenerate plasmodesmata (Erhardt et al., 2005). Both proteins are required in planta to target p42 to punctate bodies that are associated with the plasmodesmata (Erhardt et al., 2000) to enable virus movement between cells. The final ORF on RNA2 encodes a small (14-kDa) cysteine-rich protein, $\mathrm{p} 14$, that has been shown to regulate the accumulation of RNA2 (Hehn et al., 1995), and is believed to act as a suppressor of post-translational gene silencing in planta (Dunoyer et al., 2002). RNA1 and RNA2 are essential for BNYVV infection and are often referred to as the 'housekeeping genes' of the virus, whereas the smaller species (RNA3, RNA4 and RNA5) are involved in natural infection and survival mechanisms, including vector-mediated infection, virus propagation and the production of disease symptoms (Richards and Tamada, 1992).

RNA3 consists of 1775 nucleotides and encodes a 25-kDa protein (p25), which has been shown to modify foliar symptom expression in particular host plants following inoculation of the leaves (Bouzoubaa et al., 1985; Chiba et al., 2003; Jupin et al., 1992). It is also required for the proliferation of fibrous roots during natural infection of sugar beet (Koenig et al., 1991; Tamada et al., 1999). Based on these findings, it has been suggested that RNA3 is a pathogenicity determinant of BNYVV and that p25 is responsible for the symptoms of rhizomania in sugar beet (Chiba et al., 2008; Jupin et al., 1991; Tamada, 2002). Severe necrotic symptoms appear to be caused following mechanical inoculation of leaves when the $\mathrm{p} 25$ protein is able to access both the cytoplasm and nuclear compartment of the host cells (Vetter et al., 2004). Schirmer et al. (2005) identified a BNYVV isolate that harboured variations in a tetrad of amino acid residues located at positions $67-70$ on the p25 protein. Klein et al. (2007) showed that variations in these amino acids appeared to influence pathogenicity on the diagnostic host $T$. expansa. Furthermore, recent evidence has suggested that the $\mathrm{p} 25$ protein may act as the avirulence target recognised in the mechanically inoculated leaves of some BNYVV-resistant sugar beet lines (Chiba et al., 2008). RNA3 encodes two other proteins: p6.8, which is also involved in the production of necrotic symptoms in planta, and p4.6, of which the function is unknown (Jupin et al., 1991, 1992).

RNA4 is 1431 nucleotides long and contains two ORFs (Bouzoubaa et al., 1985). The major ORF encodes a 31-kDa protein (p31), which is required for efficient transmission of the virus by P. betae (Tamada and Abe, 1989); the other ORF codes for a 6.5-kDa protein of unknown function. p31 has also been implicated in other infection-related processes, such as the enhancement of BNYVV symptom expression, in hosts such as Nicotiana benthamiana, where RNA4 rather than RNA3 has been shown to be associated with severe symptom development via BNYVVmediated suppression of RNA silencing in roots (Rahim et al., 2007). It is thought that the $p 14$ and $p 31$ proteins are required specifically to suppress RNA silencing in leaves and roots, respectively.

The fifth RNA species, RNA5, is only found in some isolates of BNYVV from Asia (Koenig and Lennefors, 2000; Tamada et al., 1989), France (Koenig et al., 1997) and the UK (Harju et al. 2002; Ward et al., 2007). RNA5 has a single ORF of 1342-1347 nucleotides long, and encodes a 228-amino-acid protein, p26 (Kiguchi et al., 1996), which varies in length between isolates from Japan and Europe (Koenig et al., 1997; Miyanishi et al., 1999), and appears to be partially targeted to the nuclear compartment of infected host cells (Link et al., 2005). Isolates carrying RNA5 appear to be more pathogenic than those with just RNA1RNA4 (Heijbroek et al., 1999; Tamada et al., 1989, 1996a). The increased pathogenicity of these isolates may be the result of the activation of in planta transcription of the virus by p26 (Link et al., 2005), although this requires confirmation. Interestingly, isolates that carry RNA5 in the absence of RNA3 appear to produce a scab-like symptom in sugar beet, suggesting that both RNAs are required for rhizomania symptom development although they have distinct roles (Tamada et al., 1996a).

\section{TYPE DIFFERENTIATION OF BNYVV}

Three major types of BNYVV have been described, none of which is serologically distinct. These BNYVV variants are referred to as A-type, B-type and P-type, and can be differentiated by restriction fragment length polymorphism or single-strand conformation polymorphism patterns of RNA1, RNA2, RNA3 and RNA4, as well as by phylogenetic relationships (Koenig et al., 1995; Kruse et al., 1994; Schirmer et al., 2005). The two most common types are the A-type and B-type, which appear to demonstrate some geographical distinction, such that the A-type is more prevalent worldwide, whereas the B-type appears to be more restricted 
in its distribution, and is found mainly in France, Germany and Japan. However, the B-type has also been reported in other countries, such as the UK and Sweden, where BNYVV is thought to have been introduced from multiple overseas sources (Koenig et al., 1995; Lennefors et al., 2000; Miyanishi et al., 1999).

The sequence divergence between the A- and B-type BNYVV is low, with nucleotide identity in the range 96\%-99\% (Koenig and Lennefors, 2000; Meunier et al., 2003a; Saito et al., 1996). In particular, the CP sequence of different isolates of A- and B-type BNYVV has been shown to be highly conserved worldwide (Schirmer et al., 2005). However, there are regions, e.g. the TGB of RNA2, with sufficient differences to allow for the development of polymerase chain reaction (PCR)-based diagnostics (Ratti et al., 2005). Although it has been suggested that there is no difference in pathogenicity between the two types (Rush et al., 2006), Heijbroek et al. (1999) reported that the A-type BNYVV appeared to be slightly more pathogenic than the B-type on sugar beet cultivars. P-type BNYVV, however, appears to be more pathogenic than both the A- and B-types (Heijbroek et al., 1999).

The P-type was first isolated from the Pithiviers area in France, and was found by Koenig et al. (1995) to contain the RNA5 that had been described previously in some Japanese isolates (Tamada et al., 1989). This type has now also been reported in the UK (Harju et al. 2002) and Kazakhstan (Koenig and Lennefors, 2000). Although the presence of RNA5 does not designate an isolate as P-type BNYVV, RNA5 from P-type isolates characteristically shares about 96\% sequence identity with RNA5 from East Asian isolates (Koenig et al., 1997; Miyanishi et al., 1999; Ward et al., 2007). Sequence comparisons of the A-, B- and P-type BNYVV isolates have suggested that the $A$ - and $P$-types are more closely related than the B-type (Koenig and Lennefors, 2000; Meunier et al., 2005; Ratti et al., 2005; Schirmer et al., 2005). It is believed that the A- and B-type BNYVV became separated a long time ago (Tamada et al., 2003), and that the P-type evolved from the A-type virus.

P-type BNYVV moves more rapidly in plants than the A- or B-types and, in partially resistant cultivars, much higher levels of infection are detected in the tap roots compared with plants infected with the A- or B-types (Heijbroek et al., 1999). It has also been suggested that the P-type BNYVV may be more aggressive because, unlike other virus types, it evades the activation of plant defence responses (Klein et al., 2007). Therefore, P-type BNYVV is a considerable potential threat to sugar beet cultivation worldwide where the control of rhizomania is based solely on the use of virus-resistant cultivars (see below).

Incidents of severe rhizomania symptoms in partially resistant sugar beet have been reported recently in the USA (Liu et al., 2005). High levels of BNYVV inoculum in the soil, coupled with environmental conditions conducive to disease development, can result in the erosion of partial rhizomania resistance (Asher et al.,
2002). However, soil dilution experiments suggest that this is not the case in the soils from the USA (Rush et al., 2006). Molecular analysis of isolates from resistant plants showing symptoms indicated that they did not contain RNA5 and were most similar to A-type BNYVV (Liu et al., 2005); there were high levels of similarity between the sequences of these 'resistance-breaking' and common BNYVV isolates (Liu and Lewellen, 2007). Schirmer et al. (2005) analysed the p25 sequences of isolates from across the world, and found that those from soils in which resistance was eroded exhibited significant sequence variation, suggesting that p25 may have a role in resistance breaking. The variation in the p25 amino acid sequence of the resistance-breaking isolates in the USA was at residues 67 and 68 , where the standard isolates had an $\mathrm{AC}$ conservation, compared with $\mathrm{AF}, \mathrm{AL}, \mathrm{SY}, \mathrm{VC}, \mathrm{VL}$ and $A C$ at the same position in the resistance-breaking isolates (Liu and Lewellen, 2007). A motif of four amino acids encompassing the same region, residues $67-70$, has also been demonstrated to have a functional role in resistance breaking (Schirmer et al., 2005). In particular, the residue at position 68 of the p25 protein is thought to strongly affect the accessibility of plant host factors that specifically recognise this viral protein and enable the plant to mount a defence response against the virus (Chiba et al., 2008). In addition, recent analyses have indicated that there has been positive selection for these amino acid changes at positions 67-68 in resistance-breaking isolates (Acosta-Leal et al., 2008). Interestingly, in the French P-type isolate, this motif is represented by SYHG, which was also found in the US isolates (Liu and Lewellen, 2007). Together, these data indicate that amino acid changes in this motif may not be a consistent indicator of the resistance-breaking potential of BNYVV isolates. However, variability within this region does appear to be associated with the erosion of resistance, and this may provide a good starting point to elucidate the mechanisms involved in resistance breaking in BNYVV.

\section{CONTROL OF RHIZOMANIA}

There is no currently available pesticide effective against $P$. betae, but control of the disease has been demonstrated to be possible previously by soil fumigation with chemicals such as methyl bromide or dichloropropene/dichloropropane. This method was successful in killing the vector and increased sugar yields from 1.3 to 7.3 tonnes/ha in the USA (Martin and Whitney, 1990) and from 2.1 to 6.9 tonnes/ha in France (Richard-Molard, 1984). Despite their effectiveness, the use of these chemicals was uneconomical and damaging to the environment, and their use was phased out as part of the Montreal Protocol [United Nations Environment Programme (UNEP), 1987]. Therefore, alternative strategies for the control of rhizomania were sought. Biological control of rhizomania has been examined using both bacterial and fungal agents to suppress the colonisation of sugar beet 
roots by $P$. betae. Bacterial seed treatments using Pseudomonas fluorescens were unable to control the disease (Resca et al., 2001), although different Trichoderma species were shown to decrease levels of BNYVV by 21\%-68\% (Jakubikova et al., 2006). However, this approach is unlikely to be adopted as part of an integrated control strategy for rhizomania in the foreseeable future.

After the initial outbreaks of the virus in continental Europe, the lack of suitable chemical control measures and the perceived slow spread of the disease led to quarantine measures being put in place to prevent further dissemination of BNYVV. These measures included controls on imported planting material and soil; surveys to detect the disease; separate harvesting of contaminated areas; isolation of equipment used with infected crops; destruction of infected parts of the crop; rotational controls on infected land; and the prevention of contaminated waste being returned to uninfected fields (Asher, 2002; Dunning et al., 1984; Richard-Molard, 1985). The quarantine control of BNYVV was largely unsuccessful, although it is very difficult to assess what effect the control measures had on slowing the development of the disease (Asher, 2002). Mathematical modelling based on the invasion and spread of the disease in the UK has highlighted the difficulty of containing the spread of such a highly infectious disease, particularly when spread has occurred because of an asymptomatic phase (Stacey et al., 2004). In the light of this, the sugar beet industry has relied increasingly on alternative control strategies, primarily the use of resistant cultivars.

\section{BREEDING FOR BNYVV RESISTANCE}

The search for resistance to rhizomania disease and BNYVV began in the 1970s, but it was not until over 10 years later that the first sources were developed (reviewed by Biancardi et al., 2002; Scholten and Lange, 2000). Research in the USA by the Holly Sugar Company led to the identification of the more effective 'Holly' source of resistance (Lewellen et al., 1987). This resistance was shown to be conditioned by a single dominant gene, Rz1 (Lewellen et al., 1987; Scholten et al., 1996), which conferred high levels of partial resistance by inhibiting virus multiplication (Paul et al., 1992a). However, despite the high level of resistance achieved, a number of observations suggested that $R z 1$ resistance might be inadequate under severe disease pressure (Lewellen, 1995; Paul et al., 1993b).

A number of different sources of partial resistance to BNYVV have since been found in evaluations of Beta vulgaris ssp. maritima (Lewellen, 1997). The apparently monogenic resistance of accession WB42 appeared to be more effective than 'Holly' resistance (Paul et al., 1993b), and was thought to be based on a different mechanism (Scholten et al., 1994). Scholten et al. (1999) and Amiri et al. (2003) estimated the genetic distance between $R z 1$ and the WB42 major resistance gene ( $R z 2)$ to be 20 and $35 \mathrm{CM}$ respectively. However, in these studies, the continuously distributed populations were assigned to discrete resistant or susceptible classes, an approach that probably resulted in an overestimation of the genetic distance. Gidner et al. (2005) mapped the major resistance gene from the WB41 source $(R z 3)$ to $\sim 5 \mathrm{cM}$ from $R z 1$ on chromosome III. As WB41 and WB42 were both collected in Denmark at around the same time, it seems likely that $R z 2$ and $R z 3$ may, in fact, be the same gene. Grimmer et al. (2007) mapped $R z 4$ (from the R36 source) to chromosome III, although the relationship between $R z 4$ and the other $R z$ genes was not determined. $R z 4$ was later mapped to the same location as $R z 1$ and $R z 5$ (from the WB258 source), indicating that the three genes are likely to be allelic (Grimmer et al., 2008). Lein et al. (2007) mapped a number of bacterial artificial chromosome (BAC) clones associated with resistance gene analogues (RGAs) to chromosome III. The BAC markers fell into two clusters: one closely linked with $R z 1$ and the other possibly coinciding with $R z 2 / R z 3$. It appears that rhizomania resistance is found at two proximal, but distinct loci, with the first locus represented by alleles $R z 1, R z 4$ and $R z 5$ and the second by alleles $R z 2$ and $R z 3$. The convergence of resistance loci on chromosome III imposes a severe limitation on the ability of breeders to combine rhizomania resistance alleles derived from different sources.

The first generation of BNYVV-resistant cultivars performed better than susceptible cultivars in fields with a low to moderate rhizomania infestation (Winner, 1988), but, in fields in which no infection occurred, their yield was lower than that of susceptible cultivars. However, sugar beet breeders rapidly improved the agronomic performance of resistant cultivars. For example, when Asher et al. (2002) evaluated the suitability of BNYVV-resistant sugar beet for use in the UK, they found that, in severely infested trials, sugar yields of resistant cultivars and breeding lines were two to three times higher than those of susceptible cultivars; moreover, on rhizomania-free sites, several resistant lines exhibited sugar yields comparable with those of the highest yielding susceptible cultivars. Such improvements have continued and, in addition, cultivars have been developed that contain both $R z 1$ and $R z 2$ and show much lower infection levels with resistancebreaking isolates of BNYVV than varieties containing either $R z 1$ or Rz2 on their own (Liu and Lewellen, 2007). Nevertheless, the presence of virulent forms of BNYVV, such as the P-type, and resistance-breaking isolates suggests that further research is required to identify new sources of resistance for breeders to work with (Heijbroek et al., 1999; Liu et al., 2005). The continued reliance on resistant cultivars carrying a single resistance gene, $R z 1$, is considered to have encouraged the selection of novel resistance-breaking isolates of BNYVV in the USA (Acosta-Leal et al., 2008). Large-scale screening of germplasm of different Beta and related species for resistance to rhizomania has been attempted with some success (Luterbacher et al., 2005). However, the number of BNYVV resistance loci may be limited. If durable 
sources of BNYVV resistance cannot be found, alternative approaches to controlling the virus must be sought.

\section{RESISTANCE AGAINST THE VECTOR P. BETAE}

At the same time as the search for BNYVV resistance, some groups began to investigate the possibility of resistance to the plasmodiophorid vector $P$. betae. Although significant levels of resistance to $P$. betae were not detected in cultivated beets (Beta vulgaris ssp. vulgaris), resistance was found in some wild relatives, such as members of the section Procumbentes, Beta patellaris and Beta procumbens (Barr et al., 1995; Paul et al., 1992b), and section Corollinae (Paul et al., 1993a). P. betae zoospores have been observed to attach to and penetrate the roots in these wild species with a similar frequency as in susceptible sugar beet, but the plasmodiophorid rarely develops further, resulting in many fewer $P$. betae resting spores in their roots. Concurrent with the much reduced levels of $P$. betae in the roots of these species was a reduced level of BNYVV (Paul et al., 1992b). Rare monosomic addition lines of sugar beet carrying individual chromosomes of either B.patellaris or $B$. procumbens were used to demonstrate that genes conferring the $P$. betae resistance phenotype were located on chromosomes IV and VIII of both wild Beta species (Mesbah et al., 1997; Paul et al., 1992b). Virus levels were also substantially reduced in these addition lines. However, because of the incompatibility of both wild species with sugar beet, accessing this form of resistance through conventional breeding methods was not possible (Van Geyt et al., 1990). Partial resistance was also identified in an accession of wild sea beet, $B$. vulgaris ssp. maritima, which readily hybridizes with sugar beet (Asher and Barr, 1990).

Initial studies to identify $P$. betae-resistant germplasm were performed by microscopic examination of the roots, which was laborious and inaccurate. Subsequent, more extensive screening was made possible by the development of a recombinant antibody that specifically detects the $P$. betae glutathione $S$-transferase protein, which is present during all stages of the parasite's life cycle (Mutasa-Göttgens et al., 2000). This antibody has been utilized in an enzyme-linked immunosorbent assay (ELISA) (Kingsnorth et al., 2003), enabling the selection of $P$. betae-resistant plants in controlled environmental tests. Progeny from crosses between $P$. betae-resistant sea beet and susceptible sugar beet were shown to inherit the vector resistance trait, which also appeared to reduce the levels of BNYVV in roots. Molecular marker analysis of the progeny populations identified two interacting quantitative trait loci associated with $P$. betae resistance, located on chromosomes IV and IX (Asher et al., 2008). Vector resistance combined additively with $R z 1$-mediated virus resistance to further reduce BNYVV levels in the roots of infected plants. The combination of vector and virus resistance provides promising new opportunities for sugar beet breeders to enhance the level and durability of rhizomania resistance.

\section{TRANSGENIC RESISTANCE}

An alternative approach to controlling rhizomania by conventional breeding is the use of pathogen-derived transgenes. Initial studies of transgenic sugar beet plants expressing the BNYVV CP sequence showed that they exhibited reduced levels of virus in both glasshouse and field trials (Mannerlöf et al., 1996). Fecker et al. (1997) expressed a short-chain antibody fragment (scFv) that was specific to the BNYVV CP in N. benthamiana, and found that the transgenic plants showed partial resistance to the virus. Plants expressing the BNYVV CP-specific scFv showed a delay in the build-up of detectable BNYVV levels in the leaves following either mechanical inoculation or viruliferous $P$. betae inoculation. However, virus titres did reach levels comparable with the nontransgenic control plants later in the infection cycle. Andika et al. (2005) expressed the CP read-through domain ORF of BNYVV in $N$. benthamiana, and showed that transgenic plants exhibited very low levels of virus following inoculation with viruliferous $P$. betae. This resistance was shown to be mediated by an RNA silencing mechanism. Lennefors et al. (2006) transformed sugar beet plants with an inverted CDNA repeat of $0.4 \mathrm{~kb}$, derived from the BNYVV replicase gene. Plants expressing dsRNA of BNYVV had levels of virus in their roots that were less than or equal to those observed in the conventionally resistant control plants when challenged with B-type BNYVV in both glasshouse and field experiments. Similar levels of resistance were also observed for A-type BNYVV, whereas trials with the P-type virus indicated that the transgenic plants had significantly lower virus levels than a sugar beet cross containing the strongest combination of conventional resistance sources ( $\mathrm{C} 48 \times$ Holly). The resistant phenotype reported by Lennefors et al. (2006) also works through RNA silencing, and its stronger phenotype compared with that achieved by Andika et al. (2005) is thought to be the result of using the replicase gene to induce silencing instead of the $\mathrm{CP}$ read-through gene, which is considered to be a 'weak silencing inducer'. Levels of BNYVV in transgenic plants expressing dsRNAmediated resistance remain low during mixed infections with other viruses that naturally co-infect sugar beet during BNYVV infections. Some of these viruses possess strong RNA silencing inhibitors, such as p21 of Beet yellows virus (Reed et al., 2003), yet none of the mixed infections compromised the transgenic resistance. This suggests that the resistance could be durable in the field (Lennefors et al., 2008).

The possibility of using transgenics to confer resistance against the Polymyxa vectors of soil-borne viruses is also an attractive proposition. Research is in progress to identify candidate genes that are expressed in host and non-host plants during interactions with Polymyxa species, and could be used in transgenic strategies 
to prevent these parasites from entering their hosts and delivering the viruses (McGrann et al., 2007, 2008). Transgenic control of rhizomania is an appealing alternative to conventionally bred sugar beet cultivars, especially in areas of high disease pressure or where highly virulent isolates of the virus exist.

\section{INTERACTIONS WITH OTHER VIRUSES AND THE EFFECT ON RHIZOMANIA RESISTANCE}

Rhizomania is just one of the many viral diseases that affect sugar beet, and there is the potential for in planta interactions between these different viruses. $P$. betae is not only the vector of BNYVV, but also of Beet soil-borne virus (BSBV), Beet soil-borne mosaic virus (BSBMV), Beet oak-leaf virus (BOLV) and Beet virus $Q$. These viruses are often found in mixed infections in the same plant (Heidel and Rush, 1994; Liu and Lewellen, 2008; Meunier et al., 2003b; Prillwitz and Schlösser, 1993). The first evidence of interactions was presented by Prillwitz and Schlösser (1993), who showed that sugar beet plants that were initially infected with BSBV suffered much less damage from subsequent BNYVV infections compared with plants that were infected with BNYVV alone. Similarly, artificial inoculations of leaves on sugar beet plants with BNYVV and BSBMV demonstrated that prior inoculation with one virus offered some protection against later infection by the other (Mahmood and Rush, 1999). In these 'protected' plants, RNA from both viruses was detected, but the coat protein of the second inoculated virus was never identified, suggesting that the cross-protection functioned by preventing the replication of the second inoculated virus (Mahmood and Rush, 1999). Studies using natural soil-borne $P$. betae inoculations of sugar beet to transmit BNYVV and BSBMV indicated that
BSBMV levels in planta were always lowest during a dual infection with BNYVV (Wisler et al., 2003). This phenomenon was also observed in BNYVV-resistant genotypes where BNYVV levels were low, suggesting that co-infection of BSBMV with BNYVV causes suppression of BSBMV. More recently, Liu and Lewellen (2008) have reported that, in mixed infections of BNYVV and BOLV, levels of BNYVV are significantly lower in dual infections in both BNYVV-susceptible and BNYVV-resistant beet varieties, compared with the levels when BNYVV alone is present. These data suggest that BOLV may be able to suppress BNYVV infections. BNYVV has also been found in mixed infections with the soil-borne Beet black scorch virus (BBSV), which is not vectored by $P$. betae but by the chytrid fungus Olpidium brassicae. The current status of the interaction between these viruses is unclear, and whether or not BBSV contributes to the severity of rhizomania disease is unknown (Koenig and Valizadeh, 2008). More in-depth studies are required to understand the molecular basis of these interactions and to determine whether or not these other soil-borne viruses have a potential role in the control of BNYVV.

Rhizomania-infected plants are also often infected with 'virus yellows', a disease caused by a complex of four aphid-borne viruses of the Polerovirus and Closterovirus genera (Stevens et al., 2005). Although initially transmitted to the aerial parts of the sugar beet plant by their aphid vectors, these viruses can be translocated via the phloem to the root tissues, where they are able to interact with BNYVV. Mixed infections of BNYVV and the polerovirus Beet mild yellowing virus (BMYV) caused yield losses as great as $83 \%$, as well as significant plant loss (Fig. 3) (Stevens, 2005; Stevens and Asher, 2005). However, of particular interest was the discovery in preliminary glasshouse trials that sugar beet varieties carrying the $R z 1$ gene for rhizomania resistance appeared to allow

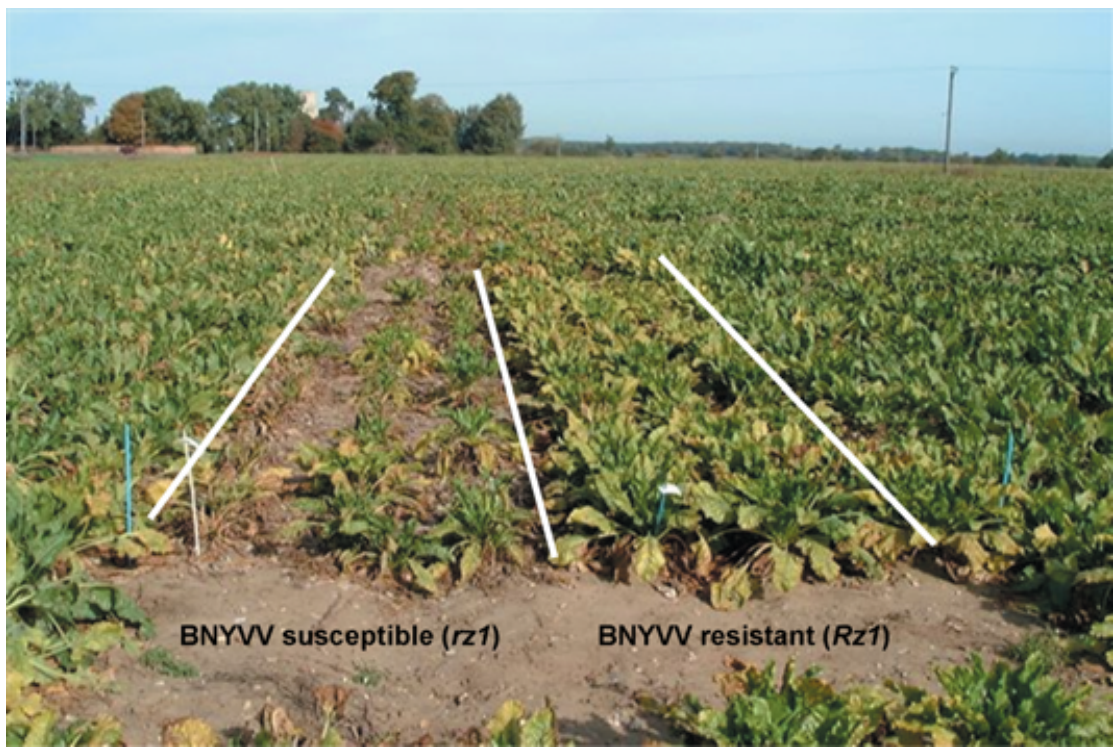

Fig. 3 Interaction between Beet necrotic yellow vein virus (BNYVV) and Beet mild yellowing polerovirus (BMYV). Plants susceptible to rhizomania and infected with both BNYVV and BMYV are severely diseased, often leading to plant loss (left), whereas plants with partial resistance to BNYVV (conferred by Rz1; right) do not appear as affected. Plants were sown in a UK rhizomaniainfested field in April 2003 and inoculated with BMYV viruliferous aphids in June 2003. Photograph was taken in October 2003. 
greater levels of BNYVV infection during mixed infections with BMYV (M. Stevens, unpublished data, Broom's Barn Research Centre, Bury St Edmunds). The possible synergy between BNYVV and BMYV requires further research to identify how and where the viruses interact. This is a particularly intriguing situation, considering the alleged compartmentalisation of the different viruses. BNYVV is principally, but not exclusively, localised to xylem vessels, whereas poleroviruses are primarily limited to the phloem and companion cells (Kaufmann et al., 1992; Stevens et al., 2005). Previous work has shown that invasion of nonphloem tissue by Potato leafroll virus, which is closely related to BMYV, is enhanced in plants also infected with the potyvirus Potato virus Y (Barker, 1987); a similar phenomenon may exist between dual infections of these aphid- and plasmodiophoridtransmitted viruses of sugar beet. Furthermore, whether this synergistic interaction has a negative effect on BNYVV resistance in the field has important implications for future control measures of viral diseases in sugar beet.

\section{CONCLUSIONS AND FUTURE PROSPECTS}

Rhizomania has had a major impact on the sugar beet industry since its discovery nearly 60 years ago. The devastating nature of the disease, coupled with the lack of effective and acceptable chemical control methods for the vector, has been a constant problem for the industry. The development of rhizomaniaresistant sugar beet has been a huge success, especially now that resistant cultivars are as high yielding as those lacking the resistance gene in the absence of the disease. However, this breeding success may be short lived, with variants of the virus capable of overcoming resistant cultivars now reported from several locations across the globe. Fortuitously, these more aggressive variants have so far been restricted geographically, and there are already new virus-resistant cultivars being released that are able to withstand these new variants. However, if no further sources of novel resistance genes can be identified, the likelihood of a future breakdown in rhizomania resistance is high. Researchers are still unsure of the specific molecular mechanisms of BNYVV resistance, and the exact nature of the $R z 1$ gene remains unknown. A knowledge of this would enable researchers to mine existing germplasm stocks for allelic variations that could increase the available gene pool for plant breeders. The use of multiple sources of resistance will help to alleviate the selection pressure currently imposed on BNYVV in the field, and thus increase the shelf life of resistant cultivars. Despite extensive knowledge of the BNYVV genome, little is understood about the basis for variation in pathogenicity, and this remains a key area of research. The relationship between p25 and p26 proteins and the increased pathogenicity of RNA5-containing isolates clearly warrants further analysis, as does the relationship between the BNYVV proteins and the different rhizomania-resistant genotypes, in order to gain a clear understanding of virus-host and resistantsusceptible interactions. One area of the rhizomania complex that remains poorly studied is the relationship between the virus and its vector. It is still unknown whether the vector population varies in its ability to transmit the virus, and at what point the virus is specifically transmitted to the host. Furthermore, the possibility of combining resistance to both the vector and virus requires further research, as does the use of transgenic resistance against BNYVV and $P$. betae. The recent evidence highlighting the importance of virus-virus interactions, the deleterious effects that these multiple infections can have on sugar beet yields and the role of induced resistance raise new questions over how best to achieve durable control of this persistent disease.

\section{ACKNOWLEDGEMENTS}

We thank Dr Mike Asher for a critical review of the manuscript. We also thank the Association of Applied Biologists for permission to use the electron micrograph image in Fig. 2. Broom's Barn Research Centre is supported by the British Beet Research Organisation (BBRO); and is the Department of Applied Crop Sciences within Rothamsted Research. GMcG was supported by the UK Biotechnology and Biological Sciences Research Council (grant 4628) through the DEFRA Sustainable Arable LINK Programme. MG was supported on BBRO grant 03/7, ESM-G was supported on BBRO grant 06/20 and MS was supported on BBRO grant 07/12.

\section{REFERENCES}

Abe, H. and Tamada, T. (1986) Association of Beet necrotic yellow vein virus with isolates of Polymyxa betae. Ann. Phytopathol. Soc. Jpn. 52 , 235-247.

Acosta-Leal, R., Fawley, M.W. and Rush, C.M. (2008) Changes in the intraisolate genetic structure of Beet necrotic yellow vein virus populations associated with plant resistance breakdown. Virology, 376, 60-68.

Adams, M.J., Antoniw, J.F. and Mullins, J.G.L. (2001) Plant virus transmission by plasmodiophorid fungi is associated with distinctive transmembrane regions of virus-encoded proteins. Arch. Virol. 146, 1139-1153.

Al Musa, A.M. and Mink, G.I. (1981) Beet necrotic yellow vein virus in North-America. Phytopathology, 71, 773-776.

Amiri, R., Moghaddam, M., Mesbah, M., Sadeghian, S.Y., Ghannadha, M.R. and Izadpanah, K. (2003) The inheritance of resistance to Beet necrotic yellow vein virus (BNYVV) in $B$. vulgaris subsp maritima, accession WB42: statistical comparisons with Holly-1-4. Euphytica, 132, 363373.

Andika, I.B., Kondo, H., and Tamada, T. (2005) Evidence that RNA silencingmediated resistance to Beet necrotic yellow vein virus is less effective in roots than in leaves. Mol. Plant-Microbe Interact. 18, 194-204.

Asher, M.J.C. (1993) Rhizomania. In: The Sugar Beet Crop (Cook D.A. and Scott, R.K., eds.), pp. 311-346. London: Chapman \& Hall.

Asher, M.J.C. (2002) The development of sugar-beet rhizomania and its control in the UK. In: BCPC Conference: Pests and Diseases, pp. 113121. Surrey: Brighton. 
Asher, M.J.C. and Barr, K.J. (1990) The host range of Polymxa betae and resistance in Beta species. In: Proceedings of the First Symposium of the International Working Group on Plant Viruses with Fungal Vectors (Koenig, R., ed.), pp. 65-68. Stuttgart: Ulmer.

Asher, M.J.C., Chwarszczynska, D.M. and Leaman, M. (2002) The evaluation of rhizomania resistant sugar beet for the UK. Ann. Appl. Biol. 141, 101-109.

Asher, M.J.C., Grimmer, M.K. and Mutasa-Göttgens, E.S. (2008) The selection and characterisation of resistance to Polymyxa betae, vector of Beet necrotic yellow vein virus, derived from wild sea beet. Plant Pathol. in press.

Barker, H. (1987) Invasion of non-phloem tissue in Nicotiana clevelandii by potato leafroll luteovirus is enhanced in plants also infected with potato Y potyvirus. J. Gen Virol. 68, 1223-1227.

Barr, K.J., Asher, M.J.C. and Lewis, B.G. (1995) Resistance to Polymyxa betae in wild Beta species. Plant Pathol. 44, 301-307.

Biancardi, E., Lewellen, R.T., De Biaggi, M., Erichsen, A.W. and Stevanato, P. (2002) The origin of rhizomania resistance in sugar beet. Euphytica, 127, 383-397.

Bouzoubaa, S., Guilley, H., Jonard, G., Richards, K. and Putz, C. (1985) Nucleotide-sequence analysis of RNA-3 and RNA-4 of Beet necrotic yellow vein virus, isolates F2 and G1. J. Gen. Virol. 66, 1553-1564.

Bouzoubaa, S., Ziegler, V., Beck, D., Guilley, H., Richards, K. and Jonard, G. (1986) Nucleotide-sequence of Beet necrotic yellow vein virus RNA-2. J. Gen. Virol. 67, 1689-1700.

Bouzoubaa, S., Quillet, L., Guilley, H., Jonard, G. and Richards, K. (1987) Nucleotide-sequence of Beet necrotic yellow vein virus RNA-1. J. Gen. Virol. 68, 615-626.

Brunt, A.A. and Richards, K.E. (1989) Biology and molecular-biology of Furoviruses. Adv. Virus Res. 36, 1-32.

Canova, A. (1959) On the pathology of sugar beet. Inf. Fitopatol. 9, 390396.

Canova, A. (1966) Si studia la rizomanie della bietola. Inf. Fitopatol. 16, 235-239.

Chiba, S., Miyanishi, M., Kondo, H. and Tamada, T. (2003) Single amino acid changes in the 25 protein of Beet necrotic yellow vein virus determine resistance responses of Beta vulgaris spp. maritima. In: Proceedings of the Fifth Symposium of the International Working Group on Plant Viruses with Fungal Vectors (Rush, C.M., ed.), pp. 5-8. Denver, CO: American Society of Sugar Beet Technologists.

Chiba, S., Miyanishi, M., Andika, I.B., Kondo, H. and Tamada, T. (2008) Identification of amino acids of the Beet necrotic yellow vein virus $\mathrm{p} 25$ protein required for induction of the resistance response in leaves of Beta vulgaris plants. J. Gen. Virol. 89, 1314-1323.

Dunning, R.A., Payne, P.A., Smith, H.G. and Asher, M.J.C. (1984) Sugarbeet rhizomania: the threat to the English crop and preventive measures being taken. In: Brighton Crop Protection Conference, pp. 779-783. Croydon: British Crop Protection Council.

Dunoyer, P., Pfeffer, S., Fritsch, C., Hemmer, O., Voinnet, O. and Richards, K.E. (2002) Identification, subcellular localization and some properties of a cysteine-rich suppressor of gene silencing encoded by Peanut clump virus. Plant J. 29, 555-567.

Erhardt, A., Vetter, G., Gilmer, D., Bouzoubaa, S., Richards, K., Jonard, G. and Guilley, H. (2005) Subcellular localization of the Triple Gene Block movement proteins of Beet necrotic yellow vein virus by electron microscopy. Virology, 340, 155-166.

Erhardt, M., Morant, M., Ritzenthaler, C., Stussi-Garaud, C., Guilley, H., Richards, K., Jonard, G., Bouzoubaa, S. and Gilmer, D. (2000) P42 movement protein of Beet necrotic yellow vein virus is targeted by the movement proteins $\mathrm{P} 13$ and $\mathrm{P} 15$ to punctate bodies associated with plasmodesmata. Mol. Plant-Microbe Interact. 13, 520-528.

Erhardt, M., Dunoyer, P., Guilley, H., Richards, K., Jonard, G. and Bouzoubaa, S. (2001) Beet necrotic yellow vein virus particles localize to mitochondria during infection. Virology, 286, 256-262.

European and Mediterranean Plant Protection Organization (OEPP/ EPPO) (2005) First record of Beet necrotic yellow benyvirus in Morocco. EPPO Reporting Service 2005, No. 7, 2005/102.

Fecker, L.F., Koenig, R. and Obermeier, C. (1997) Nicotiana benthamiana plants expressing Beet necrotic yellow vein virus (BNYVV) coat proteinspecific scFv are partially protected against the establishment of the virus in the early stages of infection and its pathogenic effects in the late stages of infection. Arch. Virol. 142, 1857-1863.

Fujisawa, I. and Sugimoto, T. (1977) Transmission of Beet necrotic yellow vein virus by Polymyxa betae. Ann. Phytopathol. Soc. Jpn. 43, 583-586.

Gao, J.L., Deng, F., Zhai, H.Q., Ling, X.S. and Liu, Y. (1983) The occurrence of sugar beet rhizomania caused by Beet necrotic yellow vein virus in China. Acta Phytopathol. Sin. 13, 1-4.

Gidner, S., Lennefors, B.L., Nilsson, N.O., Bensefelt, J., Johansson, E., Gyllenspetz, U. and Kraft, T. (2005) QTL mapping of BNYVV resistance from the WB41 source in sugar beet. Genome, 48, 279-285.

Gilmer, D., Bouzoubaa, S., Hehn, A., Guilley, H., Richards, K. and Jonard, G. (1992) Efficient cell-to-cell movement of Beet necrotic yellow vein virus requires 3' proximal genes located on RNA-2. Virology, 189, 40-47.

Grimmer, M.K., Trybush, S., Hanley, S., Francis, S.A., Karp, A. and Asher, M.J.C. (2007) An anchored linkage map for sugar beet based on AFLP, SNP and RAPD markers and QTL mapping of a new source of resistance to Beet necrotic yellow vein virus. Theor. Appl. Genet. 114, 1151-1160.

Grimmer, M.K., Kraft, T., Francis, S.A. and Asher, M.J.C. (2008) QTL mapping of BNYVV resistance from the WB258 source in sugar beet. Plant Breeding, in press

Harju, V.A., Mumford, R.A., Blockley, A., Boonham, N., Clover, G.R.G., Weekes, R. and Henry, C.M. (2002) Occurrence in the United Kingdom of Beet necrotic yellow vein virus isolates which contain RNA 5. Plant Pathol. 51, 811-811.

Hehn, A., Bouzoubaa, S., Bate, N., Twell, D., Marbach, J., Richards, K., Guilley, H. and Jonard, G. (1995) The small cysteine-rich protein p14 of Beet necrotic yellow vein virus regulates accumulation of RNA-2 in cis and coat protein in trans. Virology, 210, 73-81.

Hehn, A., Fritsch, C., Richards, K.E., Guilley, H. and Jonard, G. (1997) Evidence for in vitro and in vivo autocatalytic processing of the primary translation product of Beet necrotic yellow vein virus RNA 1 by a papainlike proteinase. Arch. Virol. 142, 1051-1058.

Heidel, G.B. and Rush, C.M. (1994) Distribution of Beet necrotic yellow vein virus, Beet distortion mosaic virus, and an unnamed soilborne sugarbeet virus in Texas and New Mexico. Plant Dis. 78, 603-606.

Heijbroek, W. (1987) Dissemination of rhizomania by water, soil and manure. In: Proceedings of the 50th Congress of the IIRB, pp. 35-43. Brussels: Institut International de Recherches Betteravieres.

Heijbroek, W. (1989) The development of Rhizomania in two areas of the Netherlands and its effect on sugar-beet growth and quality. Neth. J. Plant Pathol. 95, 27-35.

Heijbroek, W., Musters, P.M.S. and Schoone, A.H.L. (1999) Variation in pathogenicity and multiplication of Beet necrotic yellow vein virus (BNYVV) in relation to the resistance of sugar-beet cultivars. Eur. J. Plant Pathol. 105, 397-405. 
Henry, C. (1996) Rhizomania-its effect on sugar-beet yield in the UK. Br. Sug. Beet Rev. 64, 24-26.

Jakubikova, L., Subikova, V., Nemcovic, M. and Farkas, V. (2006) Selection of natural isolates of Trichoderma spp. for biocontrol of Polymyxa betae as a vector of virus causing rhizomania in sugar beet. Biologia, 61, 347351.

Jupin, I., Tamada, T. and Richards, K. (1991) Pathogenesis of Beet necrotic yellow vein virus. Semin. Virol. 2, 121-129.

Jupin, I., Guilley, H., Richards, K.E. and Jonard, G. (1992) Two proteins encoded by Beet necrotic yellow vein virus RNA-3 influence symptom phenotype on leaves. EMBO J. 11, 479-488.

Kanzawa, K. and Ui, T. (1972) A note on rhizomania of sugar beet in Japan. Ann. Phytopathol. Soc. Jpn. 38, 434-435.

Kaufmann, A., Koenig, R. and Lesemann, D.-E. (1992) Tissue printimmunoblotting reveals an uneven distribution of Beet necrotic yellow vein virus and Beet soil-borne viruses in sugarbeets. Arch. Virol. 126, 329-335.

Keskin, B. (1964) Polymyxa betae nsp ein parasit in den wurseln von Beta vulgaris Tournefort besonders wahrend der jugendentwicklung der zuckerrube. Arch. Microbiol. 49, 348-374.

Keskin, B. and Fuchs, W.H. (1969) The process of infection by Polymyxa betae. Arch. Microbiol. 68, 218-226.

Kiguchi, T., Saito, M. and Tamada, T. (1996) Nucleotide sequence analysis of RNA-5 of five isolates of Beet necrotic yellow vein virus and the identity of a deletion mutant. J. Gen. Virol. 77, 575-580.

Kingsnorth, C.S., Asher, M.J.C., Keane, G.J.P., Chwarszczynska, D.M., Luterbacher, M.C. and Mutasa-Göttgens, E.S. (2003) Development of a recombinant antibody ELISA test for the detection of Polymyxa betae and its use in resistance screening. Plant Pathol. 52, 673-680.

Klein, E., Link, D., Schirmer, A., Erhardt, M. and Gilmer, D. (2007) Sequence variation within Beet necrotic yellow vein virus $\mathrm{p} 25$ protein influences its oligomerization and isolate pathogenicity on Tetragonia expansa. Virus Res. 126, 53-61.

Koenig, R. (2000) Deletions in the KTER-encoding domain, which is needed for Polymyxa transmission, in manually transmitted isolates of Beet necrotic yellow vein benyvirus. Arch. Virol. 145, 165-170.

Koenig, R. and Lennefors, B.L. (2000) Molecular analyses of European A, $B$ and $P$ type sources of Beet necrotic yellow vein virus and detection of the rare $P$ type in Kazakhstan. Arch. Virol. 145, 1561-1570.

Koenig, R. and Valizadeh, J. (2008) Molecular and serological characterization of an Iranian isolate of Beet black scorch virus. Arch. Virol. 153, 1397-1400.

Koenig, R., Jarausch, W., Li, Y., Commandeur, U., Burgermeister, W., Gehrke, M. and Luddecke, P. (1991) Effect of recombinant Beet necrotic yellow vein virus with different RNA compositions on mechanically inoculated sugar-beets. J. Gen. Virol. 72, 2243-2246.

Koenig, R., Luddecke, P. and Haeberle, A.M. (1995) Detection of Beet necrotic yellow vein virus-strains, variants and mixed infections by examining single-strand conformation polymorphisms of immunocapture RT-PCR products. J. Gen. Virol. 76, 2051-2055.

Koenig, R., Haeberle, A.M. and Commandeur, U. (1997) Detection and characterization of a distinct type of Beet necrotic yellow vein virus RNA 5 in a sugarbeet growing area in Europe. Arch. Virol. 142, 1499-1504.

Kruse, M., Koenig, R., Hoffmann, A., Kaufmann, A., Commandeur, U., Solovyev, A.G., Savenkov, I. and Burgermeister, W. (1994) Restriction fragment length polymorphism analysis of reverse transcription PCR products reveals the existence of two major strain groups of Beet necrotic yellow vein virus. J. Gen. Virol. 75, 1835-1842.
Larson, R.L., Wintermantel, W. M., Hill, A., Fortis, L. and Nunez, A. (2008) Proteome changes in sugar beet in response to Beet necrotic yellow vein virus. Physiol. Mol. Plant Pathol. 72, 67-72.

Lein, J.C., Asbach, K., Tian, Y.Y., Schulte, D., Li, C.Y., Koch, G., Jung, C. and Cai, D.G. (2007) Resistance gene analogues are clustered on chromosome 3 of sugar beet and cosegregate with QTL for rhizomania resistance. Genome, 50, 61-71.

Lennefors, B.L., Lindsten, K. and Koenig, R. (2000) First record of A and $B$ type Beet necrotic yellow vein virus in sugar beets in Sweden. Eur. J. Plant Pathol. 106, 199-201.

Lennefors, B.L., Savenkov, E.I., Bensefelt, J., Wremerth-Weich, E., van Roggen, P., Tuvesson, S., Valkonen, J.P.T. and Gielen, J. (2006) dsRNA-mediated resistance to Beet necrotic yellow vein virus infections in sugar beet (Beta vulgaris L. ssp vulgaris). Mol. Breeding, 18, 313325.

Lennefors, B.L., Van Roggen, P., Yndgaard, F., Savenkov, E.I. and Valkonen, J.P.T. (2008) Efficient dsRNA-mediated transgenic resistance to Beet necrotic yellow vein virus in sugar beets is not affected by other soilborne and aphid-transmitted viruses. Transgenic Res. 17, 219-228.

Lewellen, R.T. (1995) Performance of near-isolines of sugarbeet with resistance to rhizomania from different sources. In: Proceedings of the 58th Congress of the IIRB, pp. 83-92. Brussels: Institut International de Recherches Betteravieres.

Lewellen, R.T. (1997) Registration of sugarbeet germplasm lines C78, C80, and C82. Crop Sci. 37, 1037.

Lewellen, R.T., Skoyen, I.O. and Erichsen, A.W. (1987) Breeding sugarbeet for resistance to rhizomania: evaluation of host-plant reactions and selection for and inheritance of resistance. In: Proceedings of the 50th Congress of the IIRB, pp. 139-156. Brussels: Institut International de Recherches Betteravieres.

Link, D., Schmidlin, L., Schirmer, A., Klein, E., Erhardt, M., Geldreich, A., Lemaire, O. and Gilmer, D. (2005) Functional characterization of the Beet necrotic yellow vein virus RNA-5-encoded p26 protein: evidence for structural pathogenicity determinants. J. Gen. Virol. 86, 2115-2125.

Liu, H. and Lewellen, R.T. (2008) Suppression of resistance-breaking Beet necrotic yellow vein virus isolates by Beet oak-leaf virus in sugar beet. Plant Dis. 92, 1043-1047.

Liu, H.Y. and Lewellen, R.T. (2007) Distribution and molecular characterization of resistance-breaking isolates of Beet necrotic yellow vein virus in the United States. Plant Dis. 91, 847-851.

Liu, H.Y., Sears, J.L. and Lewellen, R.T. (2005) Occurrence of resistancebreaking Beet necrotic yellow vein virus of sugar beet. Plant Dis. 89, 464-468.

Luterbacher, M.C., Asher, M.J.C., Beyer, W., Mandolino, G., Scholten, O.E., Frese, L., Biancardi, E., Stevanato, P., Mechelke, W. and Slyvchenko, 0. (2005) Sources of resistance to diseases of sugar beet in related Beta germplasm: II. Soil-borne diseases. Euphytica, 141, 49-63.

Mahmood, T. and Rush, C.M. (1999) Evidence of cross-protection between Beet soilborne mosaic virus and Beet necrotic yellow vein virus in sugar beet. Plant Dis. 83, 521-526.

Mannerlöf, M., Lennerfors, B.L. and Tenning, P. (1996) Reduced titer of BNYVV in transgenic sugar beets expressing the BNYVV coat protein. Euphytica, 90, 293-299.

Martin, F.N. and Whitney, E.D. (1990) In-bed fumigation for control of rhizomania of sugar-beet. Plant Dis. 74, 31-35.

McGrann, G.R.D., Martin, L.D., Kingsnorth, C.S., Asher, M.J.C., Adams, M.J. and Mutasa-Göttgens, E.S. (2007) Screening for genetic elements involved in the nonhost response of sugar beet to the plasmodiophorid 
cereal root parasite Polymyxa graminis by representational difference analysis. J. Gen. Plant Pathol. 73, 260-265.

McGrann, G.R.D., Townsend, B.J., Antoniw, J.F., Asher, M.J.C. and Mutasa-Göttgens, E.S. (2008) Barley elicits a similar early basal defence response during host and non-host interactions with Polymyxa root parasites. Eur. J. Plant Pathol. DOI: 10.1007/s10658-008-9332-z.

Mesbah, M., Scholten, O.E., deBock, T.S.M. and Lange, W. (1997) Chromosome localisation of genes for resistance to Heterodera schachtii, Cercospora beticola and Polymyxa betae using sets of Beta procumbens and B. patellaris derived monosomic additions in B. vulgaris. Euphytica, 97, 117-127.

Meunier, A., Schmit, J.F. and Bragard, C. (2003a) Sequence analysis of Belgian BNYVV and development of a simultaneous detection of soilborne sugar-beet viruses by RT-PCR. In: Proceedings of the Fifth Symposium of the International Working Group on Plant Viruses with Fungal Vectors (Rush, C.M., ed.), pp. 9-12. Denver, CO: American Society of Sugar Beet Technologists.

Meunier, A., Schmit, J.F., Stas, A., Kutluk, N. and Bragard, C. (2003b) Multiplex reverse transcription-PCR for simultaneous detection of Beet necrotic yellow vein virus, Beet soilborne virus, and Beet virus $Q$ and their vector Polymyxa betae Keskin on sugar beet. Appl. Environ. Microbiol. 69, 2356-2360.

Meunier, A., Schmit, J.F. and Bragard, C. (2005) Comparison of the Beet necrotic yellow vein virus $\mathrm{P} 75$ nucleotide sequences of Belgian type $A$ and type B sources. Virus Res. 108, 15-22.

Miyanishi, M., Kusume, T., Saito, M. and Tamada, T. (1999) Evidence for three groups of sequence variants of Beet necrotic yellow vein virus RNA 5. Arch. Virol. 144, 879-892.

Mouhanna, A.M., Nasrallah, A., Langen, G. and Schlosser, E. (2002) Surveys for Beet necrotic yellow vein virus (the cause of rhizomania), other viruses, and soil-borne fungi infecting sugar beet in Syria. J. Phytopathol. 150, 657-662.

Mutasa-Göttgens, E.S., Chwarszczynska, D.M., Halsey, K. and Asher, M.J.C. (2000) Specific polyclonal antibodies for the obligate plant parasite Polymyxa - a targeted recombinant DNA approach. Plant Pathol. 49, 276-287.

Nielsen, S.L., Nicolaisen, M., Scheel, C. and Dinesen, I.G. (2001) First record of Beet necrotic yellow vein virus in Denmark. Plant Dis. 85, 559.

Paul, H., Henken, B. and Alderlieste, M.F.J. (1992a) A greenhouse test for screening sugar beet (Beta vulgaris) for resistance to Beet necrotic yellow vein virus (BNYVV). Neth. J. Plant Pathol. 98, 65-75.

Paul, H., Henken, B., Debock, T.S.M. and Lange, W. (1992b) Resistance to Polymyxa betae in Beta species of the Section Procumbentes, in hybrids with Beta vulgaris and in monosomic chromosome additions of Beta procumbens in Beta vulgaris. Plant Breeding, 109, 265-273.

Paul, H., Henken, B., Scholten, O.E., De Bock, T.S.M. and Lange, W. (1993a) Variation in the level of infection with Polymyxa betae and its effect on infection with Beet necrotic yellow vein virus in beet accession of the sections Beta and Corollinae. In: Proceedings of the Second Symposium of the International Working Group on Plant Viruses with Fungal Vectors (Hiruki, C. ed.), pp. 133-136. Denver, C0: American Society of Sugar Beet Technologists.

Paul, H., Henken, B., Scholten, O.E. and Lange, W. (1993b) Use of zoospores of Polymyxa betae in screening beet seedlings for resistance to Beet necrotic yellow vein virus. Neth. J. Plant Pathol. 99, 151-160.

Prillwitz, H. and Schlösser, E. (1993) Interactions between Beet soil-borne virus (BSBV-2) and Beet necrotic yellow vein virus (BNYVV). In: Proceedings of the Second Symposium of the International Working Group on
Plant Viruses with Fungal Vectors (Hiruki, C. ed.), pp. 71-74. Denver, CO: American Society of Sugar Beet Technologists.

Rahim, M.D., Andika, I.B., Han, C., Kondo, H. and Tamada, T. (2007) RNA4-encoded p31 of Beet necrotic yellow vein virus is involved in efficient vector transmission, symptom severity and silencing suppression in roots. J. Gen. Virol. 88, 1611-1619.

Ratti, C., Clover, G.R.G., Autonell, C.R., Harju, V.A. and Henry, C.A. (2005) A multiplex RT-PCR assay capable of distinguishing Beet necrotic yellow vein virus types A and B. J. Virol. Methods, 124, 41-47.

Reed, J.C., Kasschau, K.D., Prokhnevsky, A.I., Gopinath, K., Pogue, G.P., Carrington, J.C. and Dolja, V.V. (2003) Suppressor of RNA silencing encoded by Beet yellows virus. Virology, 306, 203-209.

Resca, R., Basaglia, M., Poggiolini, S., Vian, P., Bardin, S., Walsh, U.F., Barreiros, C.M.E., O'Gara, F., Nuti, M.P., Casella, S. and Peruch, U. (2001) An integrated approach for the evaluation of biological control of the complex Polymyxa betae/Beet necrotic yellow vein virus, by means of seed inoculants. Plant and Soil, 232, 215-226.

Richard-Molard, M. (1984) Beet rhizomania disease: the problem in Europe. In: Brighton Crop Protection Conference, pp. 837-845. Croydon: British Crop Protection Council.

Richard-Molard, M.S. (1985) Rhizomania: a world-wide danger to sugar beet. Span, 28, 92-94.

Richards, K.E. and Tamada, T. (1992) Mapping functions on the multipartite genome of Beet necrotic yellow vein virus. Annu. Rev. Phytopathol. 30, 291-313.

Rush, C.M. (2003) Ecology and epidemiology of Benyviruses and plasmodiophorid vectors. Annu. Rev. Phytopathol. 41, 567-592.

Rush, C.M., Liu, H.-Y., Lewellen, R.T. and Acosta-Leal, R. (2006) The continuing saga of Rhizomania of sugar beets in the United States. Phytopathology, 90, 4-15.

Saito, M., Kiguchi, T., Kusume, T. and Tamada, T. (1996) Complete nucleotide sequence of the Japanese isolate $S$ of Beet necrotic yellow vein virus RNA and comparison with European isolates. Arch. Virol. 141, 2163-2175.

Schirmer, A., Link, D., Cognat, V., Moury, B., Beuve, M., Meunier, A., Bragard, C., Gilmer, D. and Lemaire, 0. (2005) Phylogenetic analysis of isolates of Beet necrotic yellow vein virus collected worldwide. J. Gen. Virol. 86, 2897-2911.

Schmitt, C., Balmori, E., Jonard, G., Richards, K.E. and Guilley, H. (1992) In vitro mutagenesis of biologically-active transcripts of Beet necrotic yellow vein virus RNA-2 - evidence that a domain of the $75-\mathrm{kDa}$ readthrough protein is important for efficient virus assembly. Proc. Natl. Acad. Sci. USA, 89, 5715-5719.

Scholten, O.E. and Lange, W. (2000) Breeding for resistance to rhizomania in sugar beet: a review. Euphytica, 112, 219-231.

Scholten, O.E., Paul, H., Peters, D., Van Lent, J.W.M. and Goldbach, R.W. (1994) In situ localisation of Beet necrotic yellow vein virus (BNYVV) in rootlets of susceptible and resistant beet plants. Arch. Virol. 91, 331-339.

Scholten, O.E., Jansen, R.C., Keizer, L.C.P., DeBock, T.S.M. and Lange, W. (1996) Major genes for resistance to Beet necrotic yellow vein virus (BNYVV) in Beta vulgaris. Euphytica, 91, 331-339.

Scholten, O.E., De Bock, T.S.M., Klein-Lankhorst, R.M. and Lange, W. (1999) Inheritance of resistance to Beet necrotic yellow vein virus in Beta vulgaris conferred by a second gene for resistance. Theor. Appl. Genet. 99, 740-746.

Sohi, H.H. and Maleki, M. (2004) Evidence for presence of types A and B of Beet necrotic yellow vein virus (BNYVV) in Iran. Virus Genes, 29, $353-$ 358. 
Stacey, A.J., Truscott, J.E., Asher, M.J.C. and Gilligan, C.A. (2004) A model for the invasion and spread of rhizomania in the United Kingdom: implications for disease control strategies. Phytopathology, 94, 209-215.

Stevens, M. (2005) Interactions between virus yellows and rhizomania. $B r$. Sug. Beet Rev. 73, 2, 4, 6, 8 .

Stevens, M. and Asher, M.J.C. (2005) Preliminary investigations into the interactions between Beet mild yellowing virus (BMYV) and Beet necrotic yellow vein virus (BNYVV) in susceptible and rhizomania-resistant varieties. Asp. Appl. Biol. 76, 13-17.

Stevens, M., Freeman, B., Liu, H.Y., Herrbach, E. and Lemaire, 0. (2005) Beet poleroviruses: close friends or distant relatives? Mol. Plant Pathol. 6, 1-9.

Stevens, M., Liu, H.-Y. and Lemaire, 0. (2006) Virus diseases. In: Sugar Beet (Draycott, A.P., ed.), pp. 256-285 Oxford: Blackwell Publishing Ltd.

Strausbaugh, C.A., Rearick, E. and Gallian, J.J. (2008) Influence of Beet necrotic yellow vein virus on sugar beet storability. Plant Dis. 92, 581587.

Tamada, T. (2002) Beet Necrotic Yellow Vein Virus. CMI/AAB Description of Plant Viruses, No. 391. Wellesbourne: Association of Applied Biologists.

Tamada, T. and Abe, H. (1989) Evidence that Beet necrotic yellow vein virus RNA-4 is essential for efficient transmission by the fungus Polymyxa betae. J. Gen. Virol. 70, 3391-3398.

Tamada, T. and Baba, T. (1973) Beet necrotic yellow vein virus from Rhizomania affected sugar beet in Japan. Ann. Phytopathol. Soc. Jpn. 39, 325-332.

Tamada, T. and Kusume, T. (1991) Evidence that the $75 \mathrm{~K}$ readthrough protein of Beet necrotic yellow vein virus RNA-2 is essential for transmission by the fungus Polymyxa betae. J. Gen. Virol. 72, 1497-1504.

Tamada, T., Shirako, Y., Abe, H., Saito, M., Kiguchi, T. and Harada, T. (1989) Production and pathogenicity of isolates of Beet necrotic yellow vein virus with different numbers of RNA components. J. Gen. Virol. 70, 3399-3409.

Tamada, T., Kusume, T., Uchino, H., Kiguchi, T. and Saito, M. (1996a) Evidence that Beet necrotic yellow vein virus RNA-5 is involved in symptom development in sugar-beet roots. In: Proceedings of the Third Symposium of the International Working Group on Plant Viruses with Fungal Vectors (Sherwood, J.L. and Rush, C.M., eds.), pp. 49-52. Denver, CO: American Society of Sugar Beet Technologists.

Tamada, T., Schmitt, C., Saito, M., Guilley, H., Richards, K. and Jonard, G. (1996b) High resolution analysis of the readthrough domain of Beet necrotic yellow vein virus readthrough protein: a KTER motif is important for efficient transmission of the virus by Polymyxa betae. J. Gen. Virol. 77, 1359-1367.
Tamada, T., Uchino, H., Kusume, T. and Saito, M. (1999) RNA 3 deletion mutants of beet necrotic yellow vein virus do not cause rhizomania disease in sugar beets. Phytopathology, 89, 1000-1006.

Tamada, T., Miyanishi, M., Kondo, H., Chiba, H. and Han, C.G. (2003) Pathogenicity and molecular variability of Beet necrotic yellow vein virus isolates from Europe, Japan, China and the United States. In: Proceedings of the Fifth Symposium of the International Working Group on Plant Viruses with Fungal Vectors (Rush, C.M., ed.), pp. 13-16. Denver, CO: American Society of Sugar Beet Technologists.

Tuitert, G. (1990) Assessment of the inoculum potential of Polymyxa betae and Beet necrotic yellow vein virus (BNYVV) in soil using the most probable number method. Neth. J. Plant Pathol. 96, 331-341.

United Nations Environment Programme (UNEP) (1987) Montreal Protocol on Substances that Deplete the Ozone Layer. UNEP Service No. 87-6106. UNEP.

Valentin, C., Dunoyer, P., Vetter, G., Schalk, C., Dietrich, A. and Bouzoubaa, S. (2005) Molecular basis for mitochondrial localization of viral particles during Beet necrotic yellow vein virus infection. J. Virology, 79, 9991-10002.

Van Geyt, J.P.C., Lange, W., Oleo, M. and Debock, T.S.M. (1990) Natural variation within the genus-Beta and its possible use for breeding sugarbeet-a review. Euphytica, 49, 57-76.

Verchot-Lubicz, J., Rush, C.M., Payton, M. and Colberg, T. (2007) Beet necrotic yellow vein virus accumulates inside resting spores and zoosporangia of its vector Polymyxa betae BNYVV infects P. betae. Virol. J. 4, 37.

Vetter, G., Hily, J.M., Klein, E., Schmidlin, L., Haas, M., Merkle, T. and Gilmer, D. (2004) Nucleo-cytoplasmic shuttling of the Beet necrotic yellow vein virus RNA-3-encoded p25 protein. J. Gen. Virol. 85, 24592469.

Ward, L., Koenig, R., Budge, G., Garrido, C., McGrath, C., Stubbley, H. and Boonham, N. (2007) Occurrence of two different types of RNA-5containing Beet necrotic yellow vein virus in the UK. Arch. Virol. 152, 59-73.

Winner, C. (1988) Terminologische fragen in der rizomaniaforschung. Zuckerindustrie, 113, 597-600.

Wisler, G.C. and Duffus, J.E. (2000) A century of plant virus management in the Salinas Valley of California, 'East of Eden'. Virus Res. 71, 161-169.

Wisler, G.C., Lewellen, R.T., Sears, J.L., Wasson, J.W., Liu, H.Y. and Wintermantel, W.M. (2003) Interactions between Beet necrotic yellow vein virus and Beet soilborne mosaic virus in sugar beet. Plant Dis. 87, 1170-1175.

Yilmaz, N.D.K., Meunier, A., Schmit, J.F., Stas, A. and Bragard, C. (2007) Partial nucleotide sequence analysis of Turkish isolates of Beet necrotic yellow vein virus (BNYVV) RNA-3. Plant Pathol. 56, 311-316. 